\title{
Comissões Permanentes de Inquérito
}

ALBERTO BONFIM

Assistente Jurídico do DASP

Todo ser vivente tem seus meios de defesa. 0 sangue possui células especiais, as hemácias, que operam a fagocitose - a devora de microrganismos que invadem o corpo e são nocivos à saúde.

A sociedade representa, em maior escala, um organismo vivo, ou, melhor, uma organização que nasce, cresce, vive e prospera, podendo enfraquecer e desaparecer como todo ser vivente.

Qualquer forma de vida, seja do reino animal, seja do vegetal, quando doente, se não fôr tratada, é óbvio que definha e morre, em vez de crescer e durar.

A natureza, que é a manifestação do próprio Deus, segundo os panteístas, já traz, em si mesma, essa fôrça imanente, que se chama defesa, ou preservação, ou, ainda, meios de sobreviVência.

Portanto, é da própria estrutura intrínseca da existência que extraímos as razões do tema sôbre que vamos dissertar e que intitula êste artigo.

Desde que o homem passou a viver em sociedade, sentiu, por automatismo, instintivamente, a necessidade de se defender, de se acautelar, de se prevenir para sobreviver.

Daí a criação de gendarmes, de vigilância, de investigações e semelhantes, para se preservar, quer de invasões externas, quer de dissensões internas.

Desde tempos imemoriais se observa que quase a totalidade dos países já possuía os seus Exércitos, suas Armadas, sua Espionagem, seu Policiamento, enfim todos os órgãos de Defesa, de Preservação ou de Sobrevivência.

E os aspectos defensivos cada vez mais se aprimoraram, embora mudando de denominação, talvez como reação a uma certa antipatia que os nomes clássicos acarretavam. 
Infelizmente os órgãos de repressão causam uma certa aversão instintiva ao povo. É que a natureza humana, lamentàvelmente ainda falha nessa parte, tende a exagerar a idéia de liberdade. As pessoas fàcilmente tendem a ultrapassar os limites convenientes ao convivio social harmônico.

Conseqüentemente se verifica uma certa inclinação para se encararem os integrantes dêsses órgãos como opressores, em vez de, como é o certo, terem-se os mesmos na conta de guardiões da ordem e da tranqüilidade que o ambiente social desfruta.

É do instinto humano, principalmente da maioria das pessoas, quando se vive em paz, infelizmente não se permitir imaginar ou encarar o reverso: que a inexistência de tais organizações traria o desassossêgo, a balbúrdia, e até o desespêro; cada qual teria de defender-se com os próprios meios ou fugir ao convívio social, ocultando-se nas florestas ou nas furnas, e mesmo aí em sobressaltos. O que normalmente ocorre é a mera idéia de opressão por parte de tais organizações.

Dêsse comportamento social adveio certa reação suavizadora dos meios repressores: tendência a evitar a farda quando fora de serviço; alterar a designação, por exemplos, de Polícia para Segurança, de policial para agente, de Exército para Defesa, de Armada para Marinha, de Espionagem para Informações, de espião para informante.

Entretanto, para as pessoas de razoável grau de compreensão e de bom nível de educação, portanto de comportamento aceitável ao convívio, a presença do policial the sugere a tranqüilidade, a do militar the lembra a proteção, a da espionagem Ihe indica a preservação. É que, ademais, nada têm a temer, como peças, que são, perfeitamente entrosadas na sociedade.

Essa verdade social se verifica em qualquer modalidade de convivência e em todos os tempos. Daí por que tais órgãos de preservação se ampliaram e até mesmo se especializaram. Em nosso país, por exemplo, há os delegados, os comissários, os procuradores, os juízes, os Tribunais de média e última instâncias; na especialização, há órgãos apuradores e judicantes, até privativos: as auditorias, para os militares, com tribunais igualmente exclusivos; a Justiça do Trabalho, para as dissidências obreiras; o Tribunal marítimo, para os acidentes de embarcação; o de Contas, para a legalidade dos gastos públicos.

Sôbre êste último, cabe lembrar, aqui, o nunca demais enaltecido Rui Barbosa, que, quando Ministro da Fazenda, 0 
criou, naturalmente, depois de certa meditação sôbre o que ocorria então com as despesas públicas, e que naturalmente ine inspirou a conhecida alocução, mais ou menos nestes têrmos, que não decoramos, mas cujo sentido nos ficou:

De tanto ver prosperar o poder nas mãos dos maus, de tanto ver vilipendiada a virtude,

de tanto ver crescer a injustiça e a impunidade, o homem de bem sente vergonha da decência, escarnece da honestidade, revolta-se contra a pureza e zomba dos bons propósitos!

Infelizmente essa verdade ainda hoje impera, embora talvez em menor escala, aqui e ali.

A atual Constituição Federal, em seus arts. 110 e 111, prevê a criação do contencioso administrativo, que naturalmente irá constituir, ou pelo menos conter também, a Justiça Administrativa, para julgar os crimes contra a Administração, bem como as demais infrações disciplinares.

Até lá, parece útil que se ampliasse, de certa forma, o poder disciplinador do funcionalismo, quando menos para se adquirir mais experiência com vistas a uma Justiça Administrativa em caráter definitivo.

Cabe, então, sugerir a ampliação das chamadas Comissões Permanentes de Inquérito (CPI), para todos os funcionários federais. Aqui se incluiriam quaisquer servidores que, de algum modo, tivessem vinculação de emprêgo com o Estado: os efetivos, os interinos, os contratados, os autárquicos, os eventuais, os recibados, enfim, quantos (e enquanto) percebessem do Erário Nacional.

Em nosso país há cêrca de trezentos mil militares, que são disciplinados por várias auditorias, com seus tribunais de instância superior.

Se os servidores públicos sobem a quase um milhão, no dizer de Belmiro Siqueira, nenhum absurdo em que tenham seus órgãos disciplinadores privativos e especializados.

Assim como os militares não sentem nenhuma humilhação em ter sua Justiça própria, mas, pelo contrário, isso Ihes garante um conceito de autodisciplinadores, para a defesa de sua integridade como classe, os funcionários civis, mais numerosos e menos disciplinados, carecem muito mais de um dispositivo especial e especializado de autopreservação; com isso merecerão melhor conceito do que atualmente têm tido.

Em São Paulo, por exemplo, é difícil a um (ex-) funcionário público conseguir colocação em emprêsas particulares. 
A noção geral que se tem dêles é a de que são preguiçosos, indolentes, incompetentes, sem iniciativa, e até desonestos... É possível mesmo que a lei da licença para os ociosos, expedida para descongestionamento das repartições, tenha fracassado por falta de empregos particulares aos servidores públicos disponíveis, em face, inclusive, daquelas impressões...

No dia em que os servidores públicos tiverem seus órgãos permanentes de preservação disciplinar em pleno funcionamento, quando os jornais divulgarem freqüentemente que 0 funcionário tal, ou qual, responde a inquérito, ou foi demitido por isso ou por aquilo, então o seu conceito social será outro: pois é certo que será expulso ao praticar desonestidade. A dúvida quanto à impunidade é que gera o desprestígio da classe perante a opinião pública.

Não há temer que os órgãos repressores ou preservadores se ampliem. Talvez alguns pensem que multiplicar ou prestigiar tais órgãos viesse sugerir a existência de cada vez maiores avanços contra o Erário: seria dar relêvo às irregularidades ou deixar entrever que elas aumentaram. Mas, com a criação de Comissões Permanentes de Inquérito para todo o funcionalismo, não há dúvida que a reação da opinião pública será a de que - Govêrno Federal está mais atento e mais zeloso para com os cofres do Estado. Isso traria fatalmente maior valorização ao funcionalismo, e à própria ação governamental.

A ampliação total de tais comissões representaria uma espécie de mal necessário. Poderia alguém preocupar-se com a despesa constante para manutenção dêsses numerosos órgãos. Mas seria como os gastos com o Seguro: salvaguardar bens contra perecimento pelos sinistros. E vale a pena segurar as repartições.

Isso dizemos em face de estar havendo um certo retrocesso da Administração na parte disciplinar. A Reforma Administrativa tocou nesse assunto apenas por alto, sòmente para afastatamento de servidores ineficientes ou desidiosos (Decreto-lei n? 200/67, art. 100).

E parece que, complementando a Reforma Administrativa, a nova reestruturação do DASP não falou nesse aspecto, que ficou, naturalmente, diluído na legislação geral de pessoal, quando, ao contrário, o caso parece que mereceria maior atenção do órgão que ora só cuida de pessoal.

A impressão que se tem é, pois, de enfraquecimento do órgão que, nessa importante questão (de pessoal), ficou à 
margem. Chegou-se mesmo à extinção da própria Seção de Regime Disciplinar, com a transformação da ex-Divisão do Regime Jurídico do Pessoal.

Todavia, acreditamos que o órgão específico de pessoal deveria cuidar de modo especialíssimo da questão disciplinar, a mola de revigoramento dos costumes e a própria garantia de uma boa administração, em todos os sentidos.

Assim, ora sugerimos a criação de mais comissões permanentes de inquérito (CPI) até à saturação de todo o funcionalismo. Não seria, por isso, uma inovação no serviço público brasileiro. Várias repartições já as conta; por exemplos: a Estrada de Ferro Central do Brasil, os Correios e Telégrafos, - Departamento de Polícia Federal, além do Govêrno do Distrito Federal, que, para a média de cada cinco mil funcionários contam com uma CPI.

É de crer ser essa uma proporção ideal: cada meia dezena de milhar de servidores justificaria perfeitamente a incumbência atribuída a quatro pessoas (um presidente, dois vogais e um(a) secretário(a) em constante vigilância quanto ao seu procedimento funcional, como uma espécie de defesa contra o deterioramento dos hábitos administrativos ou para a preservação da perfeita entrosagem do conjunto.

Dividir-se-ia o país em regiões onde atuassem quaisquer espécies de servidores federais no seu conjunto (efetivos, eventuais, recibados, de obras, autárquicos, de encargos), como já dissemos. Para cada cinco mil dêles haveria uma CPI em determinada sede, embora com deslocamentos quando necessário, para só cuidar do respectivo comportamento disciplinar, como tal desde os mínimos deslises (puníveis com repreensão) até os delitos mais graves (puníveis com demissão). Tais CPIs seriam integradas de elementos indicados pelos vários órgãos de administração, direta ou indireta, mas ficariam vinculadas ao DASP, o órgão federal geral de pessoal, para efeito de orientação, contrôle e colaboração uniforme.

Uma regulamentação, regimento ou código disciplinar comum regeria tôdas as relações disciplinares de tais servidores públicos, sob o aspecto comportamental.

Dêsse modo, para os cêrca de 1 milhão de servidores, se ainda tanto, ter-se-ia mais ou menos duzentas CPIs., que se especializariam no manuseio constante da legislação específica, evitando injustiças, quer de excessivo rigorismo, quer de cunho minimizador das sanções. Decorreria daí mais uniformidade na apreciação dos delitos administrativos com o aperfeiçoamento de tais CPIs. 
De preferência, as CPIs seriam integradas por ocupantes de cargo de nível superior, pelo menos os presidentes, que seriam detentores de investiduras privativas de Bacharéis em Direito, como os Procuradores, os Assessôres e os Assistentes Jurídicos, sempre que possivel.

Haveria, no DASP, como cúpula, um setor da Coordenação de Legislação de Pessoal (COLEPE), integrado de funcionários notòriamente conhecedores do assunto, os quais constituiriam uma outra unidade, que se denominaria, por exemplo, UNIDIS (Unidade Disciplinar), para colaborar com as CPIs, coordenando, orientando, criando normas sôbre o assunto.

Tal setor poderia conter, pelo menos, cinco funcionários especializados em regime disciplinar, inclusive requisitados, numa média de um para cada vinte CPIs.

Essa proporção pode parecer pequena, mas há que se levar em conta que tais funcionários não irão estudar todos os processos disciplinares resultantes das apurações feitas por elas. Irão tratar apenas da orientação geral, pois a interpretação cabível das leis e da jurisprudência para cada caso carecedor de consulta, seria logo comunicada oficialmente a tôdas as CPIs, mediante circulares ou publicação em órgão oficial.

Poderia eventualmente haver certa dúvida quanto ao perfeito funcionamento de tais CPIs, principalmente no que concerne à forma de entrosamento com o DASP, que sôbre elas exerceria contrôle.

Mas parece-nos que em pouco tempo de experimentação - de 3 a 5 anos, se tanto - êsse mecanismo estaria rodando macio, com tôdas as suas arestas desaparecidas pelo uso e com algumas das rodas de sua engrenagem substituidas para perfeito manuseio.

É óbvio, como dizem os alemães, que "aller anfang ist schwer" (todo o comêço é difícil). Ocorre o mesmo com as crianças: primeiro engatinham, depois andam trôpegamente, para, após, correrem e saltarem. Daí não há fugir; é regra infalível da própria natureza humana.

Pensamos que vale a pena fazermos essa experiência, ainda que de início haja algumas dificuldades, perfeitamente sanáveis.

É a nossa modesta mas leal sugestão, como pequena contribuição ao aprimoramento da Administração de Pessoal de um Brasil Grande, mas que pode e deve ser maior. 